\title{
Mites (Acari) at the edges of bog pools in Orawa-Nowy-Targ Basin (S Poland), with particular reference to the Oribatida
}

\author{
ANNA SENICZAK ${ }^{1}$, STANISŁAW SENICZAK ${ }^{2}$, JAROSŁAW KOWALSKI ${ }^{1}$, \\ RADOMIR GRACZYK ${ }^{1}$ and MARCIN MISTRZAK ${ }^{3}$ \\ ${ }^{1}$ Department of Ecology, University of Sciences and Technology in Bydgoszcz, \\ Ks. Kordeckiego 20, 85-225 Bydgoszcz, Poland \\ ${ }^{2}$ Department of Evolutionary Biology, Kazimierz Wielki University, J.K. Chodkiewicza 30, \\ 85-064 Bydgoszcz, Poland \\ ${ }^{3}$ ICL Polska Sp. z o.o., Puławska 469, 02-844 Warszawa, Poland \\ Corresponding author: Anna Seniczak, aseniczak@utp.edu.pl
}

(Received on 9 June 2014; Accepted on 8 June 2015)

\begin{abstract}
Mites, and among them especially the Oribatida, are very abundant in bogs, being good bioindicators of various changes, but little is known about their reaction to heavy industrial exploitation of bogs. This study aimed to compare the acarofauna of the edges of small pools located in 2 bogs of Orawa-Nowy-Targ Basin (Kotlina Orawsko-Nowotarska), namely Łysa Puścizna (LP) and Bór Podczerwony (BP), degraded to different degrees by peat exploitation. The area of bog LP has decreased since the end of the $19^{\text {th }}$ century by $34 \%$, while that of BP has decreased during this time drastically (by $68 \%$ ). Water in both studied pools differed from that in natural bogs, reported in the literature, especially in $\mathrm{pH}$, colour, and oxygen conditions $\left(\mathrm{COD}\right.$ and $\left.\mathrm{BOD}_{5}\right)$, and these differences were more pronounced at BP. The abundance of mites was similar to that observed in natural bogs, and the Oribatida dominated among mites, constituting over $99 \%$ of them. The species diversity of Oribatida was low in both pools, but especially in pool BP. In both bogs the aquatic species were the most abundant due to the wet study season. The species structure of Oribatida differed, however, from that reported from natural bogs as well as from each other. At the less degraded bog LP the most abundant was Hydrozetes lacustris $(D=69 \%)$, while at bog BP, with worse water parameters, Trimalaconothrus maior highly dominated $(D=93 \%)$. This suggests that the latter species is very tolerant to water parameters, being a successful coloniser of degraded bogs.
\end{abstract}

Keywords: Acari, Oribatida, Mesostigmata, Prostigmata, bog, ecology, species diversity

\section{INTRODUCTION}

Bogs have many important functions in the environment. First of all, they regulate water conditions in the landscape, as they accumulate water in wet seasons and let it run in dry seasons. They also serve as natural filters, binding toxic organic substances and heavy metals to sediments and thus cleaning water. Moreover, 
bogs create interesting habitats, with the specific flora and fauna, and thus increase the landscape biodiversity (TOBOLSKi 2000; NAMURA-OCHALSKA 2008). They are also of high economic value, e.g. producing peat or berries. However, intensive peat extraction and the associated bog drainage lead to the degradation of bogs and result in the loss of their values, including the loss of biodiversity.

The bogs of the Orawa-Podhale region (within the current Polish borders) were in good condition until the second half the $19^{\text {th }}$ century and at that time they covered about 4282 ha. Later, however, they were exploited intensively, which led to a decrease in their total area, disappearance of some bogs, and drying of the peat, and that in turn decreased their water retention capacity. The total area of bogs in OrawaPodhale region decreased in $1894-2000$ by $34 \%$ and their water accumulation was reduced by $30 \%$ (LAJCZAK 2006).

Mites, and among them especially the Oribatida, are very abundant in bogs, reaching the densities of several hundred thousand per $\mathrm{m}^{2}$ (SENICZAK 2011b). They are known to be good bioindicators of anthropogenic changes, like those caused e.g. by forest drainage, fertilization (MARKKULA 1981, 1982, 1986a, b) or trampling (BORCARD \& MAтTHey 1995). Little is known, however, about the effect of heavy industrial exploitation of bogs, like those in Orawa-Nowy-Targ Basin, on the mite communities.

The aim of this study was to compare the acarofauna at the edges of 2 peat pools located in bogs of Orawa-Nowy-Targ Basin in southern Poland, which were degraded to varying degrees by peat exploitation. We hypothesized that: (1) mite communities of degraded bogs differ from those of natural bogs, known from the literature; among the Oribatida we expected a shift towards eurytopic species; (2) mite communities differ between the 2 studied bogs, depending on their water conditions.

\section{MATERIAL AND METHODS}

\section{Study area}

Samples were taken from the edges of 2 peat pools located in unprotected bogs: Łysa Puścizna (hereafter referred to as pool LP) and Bór Podczerwony (pool BP), also known as Bór za Lasem Kaczmarka, in Orawa-Nowy-Targ Basin (Kotlina OrawskoNowotarska) in southern Poland. Both pools LP $\left(49^{\circ} 25^{\prime} 47^{\prime \prime} \mathrm{N}\right.$; $19^{\circ} 42^{\prime} 50^{\prime \prime} \mathrm{E}, 650 \mathrm{~m}$

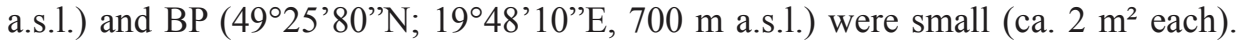
Their edges were formed by the plant association Eriophorum vaginatum-Sphagnum fallax Hueck 1928. At pool LP, about $10 \%$ of the investigated area were covered by Eriophorum angustifolium, 60\% by Sphagnum fallax, and 30\% by Polytrichum strictum At BP, 95\% were covered by Sphagnum fallax, while 5\% by Eriophorum angustifolium Honck. (Krasicka-Korczyńska, unpublished data).

The bogs of Orawa-Nowy-Targ Basin were heavily exploited in 1894-2000, and that resulted in drastic changes in their area and water regime. Bog LP covers 101.25 ha, so its area has decreased by $34 \%$ in comparison to the year 1894 . The average peat depth is $1.68 \mathrm{~m}$ and the maximum is $3.80 \mathrm{~m}$. Bog BP today covers 116.25 ha, so its area has decreased by $68 \%$ in comparison to 1894 . The mean peat depth in the part of the bog that was industrially exploited is $1.35 \mathrm{~m}$, while the maximum peat depth of the part that was not exploited industrially is 3.65 m (ŁAJCZAK 2006). 


\section{Water analyses}

For the water analyses, $3 \mathrm{dm}^{3}$ of water were taken from each pool. The samples were analysed in the authorized Laboratory of Environmental Protection (Naftobazy Baza Paliw No. 2) in Nowa Wieś Wielka. The measured parameters and used methods are given in Table 1.

Table 1. Physicochemical parameters of water in peat pools located in bogs in Orawa-Nowy-Targ Basin: Łysa Puścizna (LP) and Bór Podczerwony (BP)

\begin{tabular}{lcrr}
\hline \multirow{2}{*}{ Parameter } & Method & \multicolumn{2}{c}{ Pool } \\
\cline { 2 - 4 } pH & pH meter, PN-90/C-04540.01 & \multicolumn{1}{c}{ LP } & BP \\
Conductivity $(\mathrm{mS} / \mathrm{cm})$ & PN-EN 27888:1999 & 140.0 & 3.6 \\
Colour $\left(\mathrm{mgPt}^{\prime} /\right)$ & PN-EN ISO7887 & 42.4 & 130.9 \\
$\mathrm{COD}\left(\mathrm{mgO}_{2} / 1\right)$ & PN-74/C-04578.03 & 114.2 & 218.4 \\
$\mathrm{BOD}_{5}\left(\mathrm{mgO}_{2} / 1\right)$ & PN-EN 1899-1:2002, PN-EN 1899-2:2002 & 5.4 & 9.1 \\
$\mathrm{Chlorides}(\mathrm{mg} / 1)$ & PN-75/C-04617.02, PN-ISO 9297:1994 & 33.0 & 46.2 \\
Sulphates $(\mathrm{mg} / 1)$ & PN-74/C-04566.09 & 4.5 & 4.1 \\
Total phosphorus $(\mathrm{mg} / 1)$ & PN-88 C-04537/04, PN-EN 1189:2000 & 0.05 & 0.16 \\
Total iron $(\mathrm{mg} / 1)$ & PN-ISO 6332:2001 & 2.0 & 1.4 \\
\hline
\end{tabular}

\section{Mite analyses}

From the edges of the pools, samples of Sphagnum mosses (each $100 \mathrm{~cm}^{2}$ in area and $5 \mathrm{~cm}$ in depth) were taken in replicates of 10 in spring in 2009 . The mites were extracted in Tullgren funnels and preserved in $70 \%$ ethanol. The nomenclature of the mite groups follows LiNDQUisT et al. (2009), while that of Oribatida follows Weigmann (2006) and partly Behan-Pelletier (1989) and Seniczak et al. (2007).

The basic statistical analyses included the minimum, maximum, and mean values of mite abundance $\left(A\right.$, in $10^{3}$ individuals $\left./ \mathrm{m}^{2}\right)$. For the other statistical analyses, the values were log-transformed $\ln (\mathrm{x}+1)$ (ŁOMNICKI 2010). Normality of the distribution was tested with the Kolmogorov-Smirnov test, while the equality of variance in different samples, with the Levene test. The assumption of normality or equality of variance was not met, so the non-parametric Kruskal-Wallis one-way analysis of variance (ANOVA) by ranks was used and then multiple comparison test average ranks were used. The level of significance for all statistical tests was accepted at $\alpha=$ 0.05. The Kruskal-Wallis test was followed by the Mann-Whitney $U$ test. Statistical calculations were carried out with STATISTICA 10.0 software.

Additionally, the dominance $(D)$ and constancy $(C)$ indices of major oribatid species, the total number of species $(S)$ of Oribatida, as well as Shannon $\left(H^{\prime}\right)$, Jaccard $(\mathrm{Ja})$, and Renkonen $(\mathrm{Re})$ indices of Oribatida were calculated. 


\section{RESULTS}

Water in pool BP had lower $\mathrm{pH}$ but higher values of most other physicochemical parameters than water in pool LP (Table 1). The major differences were in water colour and phosphorus concentration, which were 3-fold higher in pool BP than in pool LP. Chemical oxygen demand (COD) and biological oxygen demand $\left(\mathrm{BOD}_{5}\right)$ were nearly 2-fold higher, while conductivity and concentration of chlorides were 1.5-fold higher in pool BP than in pool LP.

The analyses of acarofauna were based on 22054 mites obtained from a total of 20 samples, including 21950 oribatid mites (12 103 juveniles) of 36 species. In both bogs the Oribatida dominated among mites, making up over $99 \%$ of them. The second most abundant group in pool BP were the Mesostigmata, followed by 'other Acari' (represented mostly by Prostigmata), while in pool LP, 'other Acari' were followed by the Mesostigmata (Table 2). The abundance of all mites and of the Oribatida was 2-fold higher in pool BP than in pool LP. The number of species and the species diversity of Oribatida were low in both pools. The compared pools were also characterised by low values of Jaccard index $(\mathrm{Ja})$ and Renkonen index $(\mathrm{Re})$, respectively.

Table 2. Abundance $\left(A\right.$, in $10^{3}$ individuals $\left./ \mathrm{m}^{2}\right)$ of some groups of Acari, number of species $(S)$, Shannon $\left(H^{\prime}\right)$, Jaccard $(\mathrm{Ja})$, and Renkonen $(\mathrm{Re})$ indices of Oribatida in peat pools located in bogs in Orawa-Nowy-Targ Basin: Łysa Puścizna (LP) and Bór Podczerwony (BP). SD = standard deviation; $H=$ result of Kruskal-Wallis analysis of variance (ANOVA) between LP and BP

\begin{tabular}{|c|c|c|c|c|}
\hline & \multirow{2}{*}{ Pool LP } & \multirow{2}{*}{ Pool BP } & \multicolumn{2}{|c|}{ Kruskal-Wallis ANOVA } \\
\hline & & & $H$ & $p$ \\
\hline \multicolumn{5}{|c|}{ Abundance mean $\pm \mathrm{SD}$ (and range) } \\
\hline Total Acari & $71.2 \pm 0.5(25.0-153.1)$ & $149.3 \pm 0.4(62.8-236.4)$ & 8.251 & 0.004 \\
\hline Oribatida & $71.0 \pm 0.5(25.0-152.8)$ & $148.5 \pm 0.4(62.7-236.3)$ & 8.252 & 0.004 \\
\hline Mesostigmata & $0.0 \pm 0.0(0.0-0.1)$ & $0.8 \pm 0.5(0.0-2.1)$ & 3.150 & 0.046 \\
\hline Other Acari & $0.2 \pm 0.2(0.0-0.6)$ & $0.1 \pm 0.0(0.0-0.3)$ & 0.773 & 0.379 \\
\hline \multicolumn{5}{|l|}{ Oribatida } \\
\hline No. of species $(S)$ & 21 & 24 & & \\
\hline Shannon index $\left(H^{\prime}\right)$ & 0.959 & 0.387 & & \\
\hline Jaccard index $(\mathrm{Ja})$ & \multicolumn{2}{|c|}{$25 \%$} & & \\
\hline Renkonen index $(R e)$ & \multicolumn{2}{|c|}{$17 \%$} & & \\
\hline
\end{tabular}

Most of the recorded oribatid species had low abundance at the studied pools and only 5 of them had dominance indices above 1\%: Hydrozetes lacustris (Michael, 1882), Limnozetes ciliatus (Schrank, 1803), L. foveolatus Willmann, 1939, Trimalaconothrus foveolatus Willmann, 1931, and T. maior (Berlese, 1910). 
Interestingly, the compared pools differed significantly in the species composition of Oribatida (Table 3). In pool LP, Hydrozetes lacustris highly dominated $(D=69 \%)$, while Trimalaconothrus foveolatus was the second most abundant, followed by Trimalaconothrus maior and Limnozetes foveolatus. The other 17 species found in this pool had dominance indices below 1\%. In pool BP, T. maior highly dominated the oribatid community, with a dominance index of $93 \%$, and only 2 other species ( $T$. foveolatus and Limnozetes ciliatus) out of the total of 24 , had dominance indices above $1 \%$.

Table 3. Abundance $\left(A\right.$, in $10^{3}$ individuals $\left./ \mathrm{m}^{2}\right)$, dominance $(D)$ and constancy $(C)$ indices of major Oribatida (with $D>1 \%$ ) in peat pools located in bogs in Orawa-Nowy-Targ Basin: Łysa Puścizna (LP) and Bór Podczerwony (BP). SD = standard deviation; $H=$ result of Kruskal-Wallis analysis of variance (ANOVA) between LP and BP. Species with $D \leq 1$ are listed under the table, with the abbreviation of the pool where they occurred

\begin{tabular}{|c|c|c|c|c|c|c|c|c|}
\hline \multirow{2}{*}{ Species } & \multicolumn{3}{|c|}{ Pool LP } & \multicolumn{3}{|c|}{ Pool BP } & \multicolumn{2}{|c|}{$\begin{array}{c}\text { Kruskal-Wallis } \\
\text { ANOVA }\end{array}$} \\
\hline & $\begin{array}{c}A \\
\text { mean } \pm \mathrm{SD} \\
\text { and range }\end{array}$ & $D$ & $C$ & $\begin{array}{c}A \\
\text { mean } \pm \mathrm{SD} \\
\text { and range }\end{array}$ & $D$ & $C$ & $H$ & $p$ \\
\hline $\begin{array}{l}\text { Hydrozetes lacustris } \\
\text { (Michael, 1882) }\end{array}$ & $\begin{array}{c}49.3 \pm 0.7 \\
10.7-143.6\end{array}$ & 69.5 & 100 & $\begin{array}{l}0.6 \pm 0.3 \\
0.0-1.2\end{array}$ & 0.4 & 90 & 14.339 & 0.000 \\
\hline $\begin{array}{l}\text { Limnozetes ciliatus } \\
\text { (Schrank, 1803) }\end{array}$ & $\begin{array}{l}0.3 \pm 0.2 \\
0.1-0.7\end{array}$ & 0.4 & 100 & $\begin{array}{l}1.8 \pm 0.5 \\
0.5-8.1\end{array}$ & 1.2 & 100 & 12.506 & 0.001 \\
\hline $\begin{array}{l}\text { L. foveolatus } \\
\text { Willmann, } 1939\end{array}$ & $\begin{array}{l}1.5 \pm 0.6 \\
0.1-5.6\end{array}$ & 2.2 & 100 & $\begin{array}{l}1.0 \pm 0.4 \\
0.0-3.3\end{array}$ & 0.7 & 90 & 0.416 & 0.519 \\
\hline $\begin{array}{l}\text { Trimalaconothrus } \\
\text { foveolatus Willmann, } \\
1931\end{array}$ & $\begin{array}{l}11.2 \pm 0.6 \\
3.1-34.0\end{array}$ & 15.8 & 100 & $\begin{array}{l}5.7 \pm 0.5 \\
1.9-13.8\end{array}$ & 3.8 & 100 & 3.025 & 0.082 \\
\hline $\begin{array}{l}\text { T. maior } \\
\text { (Berlese, 1910) }\end{array}$ & $\begin{array}{l}8.0 \pm 0.5 \\
2.6-15.9\end{array}$ & 11.2 & 100 & $\begin{array}{c}137.6 \pm 0.5 \\
58.0-226.9\end{array}$ & 92.7 & 100 & 14.285 & 0.000 \\
\hline
\end{tabular}

Achipteria coleoptrata (Linné, 1758) (LP); Chamobates pusillus (Berlese, 1895) (LP); Dissorhina ornata (Oudemans, 1900) (LP); Eupelops occultus (C. L. Koch, 1835) (BP); E. plicatus (C. L. Koch, 1836) (BP); Fuscozetes fuscipes (C. L. Koch, 1844) (BP); Galumna obvia (Berlese, 1915) (BP); Hydrozetes octosetosus Willmann, 1932 (LP); Hypochthonius rufulus C. L. Koch, 1835 (LP); Limnozetes lustrum Behan-Pelletier, 1989 (BP); Liochthonius alpestris (Forsslund, 1958) (BP); L. furcillatus (Willmann, 1942) (BP); L. peduncularis (Strenzke, 1951) (BP, LP); Malaconothrus monodactylus (Michael, 1888) (LP); Mucronothrus nasalis (Willmann, 1929) (LP); Nanhermannia cf. coronata Berlese, 1913 (BP); Oppiella nova (Oudemans, 1902) (BP, LP); O. translamellata (Willmann, 1923) (BP, LP); Oribatula interrupta (Willmann, 1939) (LP); Pergalumna nervosa (Berlese, 1914) (LP); Pilogalumna tenuiclava (Berlese, 1908) (LP); Platynothrus peltifer (C. L. Koch, 1839) (BP); Punctoribates sellnicki Willmann, 1928 (LP); Scheloribates laevigatus (C. L. Koch, 1836) (BP); S. latipes (C. L. Koch, 1844) (BP, LP); S. quintus Wunderle, Beck \& Woas, 1990 (BP); Suctobelbella acutidens lobata (Strenzke, 1951) (BP); S. palustris (Forsslund, 1953) (BP); Tectocepheus velatus (Michael, 1880) (BP); Trimalaconothrus sculptus Knülle, 1957 (LP); Zetomimus furcatus (Pearce \& Warburton, 1906) (BP) 


\section{DISCUSSION}

Bogs offer extreme conditions to the mites living there, due to the waterlogged substrate and low $\mathrm{pH}$. Acidic water is characteristic for bogs, as many Sphagnum species growing there decrease water pH (RYdin \& JEGLUm 2006). However, peat exploitation, connected with drainage, leads to a further decease in water $\mathrm{pH}$ and increase in the conductivity of water and its colour value (BANAŚ \& Gos 2004). High water colour values result from the high amount of humic substances suspended in water and lead in turn to worse oxygen conditions (RYDIN \& JEGLUM 2006).

Water of both studied pools differed from that of natural bogs and transitional mires studied in northern Poland (SENICZAK 2011b), especially in pH, colour, COD and $\mathrm{BOD}_{5}$, and these differences were more pronounced in pool BP. The differences among the studied bogs can be probably explained by different degrees of their exploitation (LAJCZAK 2006). Changed water conditions at degraded bogs did not affect mite density, which was similar as in the natural mires (where it ranged from 53.5 to 177.7 thousand individuals per $\mathrm{m}^{2}$ ). The differences in mite abundance between bogs LP and BP can be explained by different species composition there.

In the studied pools the most abundant group of mites were the Oribatida, like in the mires in northern Poland, but the abundance of Mesostigmata differed between the natural mires and those degraded by human activity (SENICZAK 2011b). In the natural mires, the Mesostigmata were less abundant than in the bogs degraded by peat exploitation, like bog BP studied here or bog Bagno Chlebowo studied earlier (SENICZAK 2011b) or by drainage, like bog Kurze Grzędy (SEniczaK 2011b). Similarly, MarkKula (1982) observed in Finland that in a drained and fertilized bog the abundance of Mesostigmata increased. It seems that drier conditions in degraded bogs are more favourable for the Mesostigmata, as these mites avoid high humidity (KacZMAREK et al. 2006; MARQuARDT 2007).

In contrast, the Oribatida are abundant at water edges, in both natural and degraded bogs. However, very few species are adapted to these extreme conditions, and the species diversity of Oribatida in bogs is very low. The number of species in both pools was similar as in the natural mires (where it ranged from 22 to 33 species), while the Shannon $\left(H^{\prime}\right)$ species diversity index at LP was comparable to that in the natural mires (0.70-2.20) (SENICZAK 2011b), but in BP it was lower. Interestingly, the number of species was higher at pool BP (24) than at pool LP (21). In contrast, the Shannon species diversity index $\left(H^{\prime}\right)$ was at pool LP 2.5-fold higher than at pool BP. That indicates a higher evenness of the species in pool LP.

The species structure of Oribatida differed between the natural mires and those degraded by various forms of human activity. In all the studied natural bogs in northern Poland the most abundant species was Limnozetes foveolatus Willmann, 1939, while in bog Bagno Chlebowo, degraded by peat exploitation, the most abundant was Zetomimus furcatus (Warburton \& Pearce, 1905), followed by Limnozetes lustrum Behan-Pelletier, 1989. In bog Kurze Grzędy, degraded by drainage, the dominant was an eurytopic species, Oppiella nova (Oudemans, 1902), which was also abundant in exploited bogs in Gorkovskaya Oblast in Russia (CHISTYAKOv 1972). In the present 
study both pools differed from the natural mires (SENICZAK 2011b) as well as from each other.

In pool LP the most abundant was an aquatic species, Hydrozetes lacustris. This mite prefers very acidic water (WaLgRAm 1976; Weigmann 2006; Weigmann \& Deichsel 2006) and is often found on floating Sphagnum moss and algae (WiLlmanN 1931; Popp 1962; Weigmann 2006; Weigmann \& Deichsel 2006). It is parthenogenetic and reproduces by thelytoky, but seems to reproduce only in summer (Popp 1962; SENICZAK 2011b). Interestingly, H. lacustris tolerated high concentrations of sulphur and poor oxygen conditions in the peat pool in bog Bagno Chlebowo and achieved high densities there, being accompanied by H. octosetosus (SENICZAK 2011a, b), although another species, H. longisetosus S. Seniczak \& A. Seniczak, 2009, was absent there, while it is the most abundant in the natural mires of northern Poland.

In pool BP the dominant species was Trimalaconothrus maior, which had a very high dominance index (92.7\%). This species is able to live in bogs degraded by peat exploitation and was also found in the peat pool in Bagno Chlebowo (SENICZAK 2011b), and in pool LP, but its abundance was far lower there than in pool BP, while its dominance was similar to that in pool LP. Trimalaconothrus maior lives mainly in oligotrophic mires (bogs) and was classified by STARÝ (1988) as a tyrphophile (i.e. species characteristic of bogs but not confined to them). It is an aquatic species and water conditions seem to be the limiting factor for it. In the studied humidity gradients it was always the most abundant in the moistest parts (DonALDSON 1996; SENICZAK 2011b). In bogs degraded by peat exploitation, water retention capacity is lower than in natural bogs, but in some seasons, after rainfalls, the water conditions can be favourable for some aquatic species, like T. maior. It is parthenogenetic like Hydrozetes lacustris, but in contrast to the latter species it reproduces throughout the year (SENICZAK 2011b), so it is able to multiply quickly and can quickly colonize favourable habitats. Trimalaconothrus maior seems to be more tolerant to water parameters than Hydrozetes lacustris, as it was abundant in the more degraded bog, with worse water parameters.

The dominance of aquatic species at both bogs indicates good water conditions due to the wet study season. When comparing the obtained results with those from bog LP in spring 2008 (SENICZAK et al. 2013), huge differences in the abundance of mites and the species structure of Oribatida can be seen. In spring 2008 the abundance of mites was only one third of that in spring 2009 studied here. In contrast to the present study, one year earlier the most abundant species, with the dominance index 40\%, was Trimalaconothrus foveolatus, which is more tolerant of the humidity conditions (SENICZAK 2011b). The second most abundant was eurytopic species Oppiella nova (Oudemans, 1902), with a dominance index of $21 \%$, while the aquatic species were less abundant. These differences can be explained by different climatic conditions in both years, which affected in turn the water regime of bogs. In 2008, the mean annual temperature was $6.7^{\circ} \mathrm{C}$ and annual rainfall was $655.1 \mathrm{~mm}$, while in 2009 the temperature was lower $\left(5.9^{\circ} \mathrm{C}\right)$ but rainfall was higher $(723.5 \mathrm{~mm})$, so that probably improved the water conditions in the bog (MisTRZAK 2013). In contrast to natural bogs, which have good water retention properties, the bogs degraded by human activity have a much lower capacity to accumulate water and they depend 
more on the climate. The lower temperature limits the evaporation, and high rainfall improves the water balance. The mites are sensitive indicators of humidity changes and quickly react to them by changing their abundance and community structure; therefore they seem to be a good tool for monitoring the conditions of the bogs.

\section{CONCLUSIONS}

1. The mite communities of degraded bogs differ from those of natural bogs known from the literature.

2. In degraded bogs the water conditions, and consequently the mite communities, depend to a large extent on the weather; if the water conditions are favourable due to a wet season, the aquatic Oribatida dominate, while in dry seasons, a shift towards eurytopic species is observed.

3. The species structure of Oribatida differed between the studied bogs. At the less degraded bog LP the most abundant was Hydrozetes lacustris, while at bog BP, with worse water parameters, Trimalaconothrus maior highly dominated. That suggests the latter species is more tolerant in respect of water conditions and is a good coloniser of degraded bogs.

Acknowledgements: We are grateful to Dr. Ewa Krasicka-Korczyńska (Department of Botany and Ecology, University of Sciences and Technology in Bydgoszcz) for the plant analyses at the study sites.

\section{REFERENCES}

BANAŚ K., Gos K. 2004. Effect of peat-bog reclamation on the physico-chemical characteristics of the ground water in peat. Pol. J. Ecol. 52: 69-74.

Behan-Pelletier V. M. 1989. Limnozetes (Acari: Oribatida: Limnozetidae) of northeastern North America. Can. Ent. 121: 453-506.

Borcard D., Matthey W. 1995. Effect of controlled trampling of Sphagnum mosses on their oribatid mite assemblages (Acari, Oribatei). Pedobiologia 39: 219-230.

Chistyakov M. P. 1972. Fauna oribatidnyh kleshcej vyrabotannyh torfyanikov [Fauna of oribatid mites of exploited peatlands]. Učenye zapiski gor'kovskogo gosudarstviennogo pedagogičeskogo instituta. Ser. Biol. Nauk 130: 79-85 (in Russian).

Donaldson G. M. 1996. Oribatida (Acari) associated with three species of Sphagnum at Spruce Hole Bog, New Hampshire, U. S. Can. J. Zool. 74: 1713-1720.

Kaczmarek S., Marquardt T., Marcysiak K., Badzińska M. 2006. Mites (Acari) of peatlands in the 'Wielkie Torfowisko Batorowskie' Reserve and the 'Bagno Stawek' Reserve, with particular reference to the Gamasida. In: Advances in Polish Acarology (GABRYś G., IGNATOwICZ S., Eds.), pp. 168-173, Wyd. SGGW, Warszawa.

Lindquist E. E., Krantz G. W., Walter D. E. 2009. Classification. In: A manual of Acarology $3^{\text {rd }}$ ed. (Krantz G.W., Walter D. E., Eds.), pp. 97-103, Texas Tech. University Press, Lubbock.

ŁaJCZAK A. 2006. Torfowiska Kotliny Orawsko-Nowotarskiej [Peatlands of Orawa-Nowy-Targ Basin], Kraków PAN, 1-147 (in Polish).

ŁomNICKI A. 2010. Wprowadzenie do statystyki dla przyrodników [Introduction to statistics for biologists]. PWN Warszawa, 1-282 (in Polish).

MarkKULA I. 1981. Vertical distribution of soil animals in a virgin and drained raised bog. SUO 32: $126-129$. 
MARKKULA I. 1982. Effect of drainage and NPK-fertilization on soil animals of a raised bog. SUO 33: 55-63.

MarkKula I. 1986a. Comparison of present and subfossil oribatid faunas in the surface peat of a drained pine mire. Ann. Ent. Fenn. 52: 39-41.

MarkKula I. 1986b. Comparison of the communities of oribatids (Acari: Cryptostigmata) of virgin and forest ameliorated pine bogs. Ann. Zool. Fenn. 23: 33-38.

MARQUARDT T. 2007. Gamasida (Acari) siedlisk borowych i torfowiska przejściowego Rezerwatu 'Bagno Stawek' w Zaborskim Parku Krajobrazowym [Gamasida (Acari) of pine forest and transition bog habitats in 'Bagno Stawek' Reserve in Zaborski Landscape Park]. PhD dissertation, Kazimierz Wielki University Bydgoszcz, Poland, 1-87 (in Polish).

MistrzaK M. 2013. Roztocze (Acari) strefy brzegowej torfowisk Kotliny Orawsko-Nowotarskiej i Tatr, $z$ analizą gatunkową mechowców (Oribatida) [Mites (Acari) of the bog edges of Orawa-Nowy-Targ Basin and the Tatras, with species analysis of moss mites (Oribatida)]. $\mathrm{PhD}$ dissertation, Kazimierz Wielki University Bydgoszcz, Poland, 1-86 (in Polish).

Namura-OchalsKa A. 2008. Śródleśne jeziora oligo-humotroficzne jako naturalne zbiorniki retencyjne [Oligo-humotrophic mid-forest lakes as natural retention reservoirs]. Stud. Mater. Cent. Eduk. Przyr. Leś. 2: 125-139 (in Polish).

Popp E. 1962. Semiaquatile Lebensräume (Bülten) in Hoch- und Niedermooren. 2 Teil. Die Milbenfauna [Semi-aquatic habitats (hummocks) of raised bogs and fens. (2nd Part. The mite fauna)]. Int. Rev. Ges. Hydrobiol. 47: 533-579 (in German).

Rydin H., JeGLum J. K. 2006. The biology of peatlands. Oxford University Press, 1-343.

SENICZAK A. 2011a. Ecology of Hydrozetes Berlese, 1902 (Acari, Oribatida) at various water bodies near Bydgoszcz (northern Poland). Biological Lett. 48: 185-192.

SENICZAK A. 2011b. Mites (Acari) of the shores of forest lakes and ponds in northern Poland, with species analysis of Oribatida. University of Technology and Life Sciences, Bydgoszcz, Poland, 1-231.

Seniczak A., Seniczak S., Mistrzak M., Nowicka A., Krasicka-KorczyŃska E. 2013. Moss mites (Acari, Oribatida) at the edges of bog lakes and pools in Brodnica Lakeland (Pojezierze Brodnickie) and Orawa-Nowy-Targ Basin (Kotlina Orawsko-Nowotarska). Biological Lett. 50: $105-112$.

Seniczak S., Solhøy T., Seniczak A. 2007. Systematic status of Hydrozetes octosetosus Willmann, 1932 (Acari: Oribatida: Hydrozetidae) in the light of ontogenetic and ecological studies. J. Nat. Hist. 41: 2081-2098.

StaRÝ J. 1988. Pancířníci (Acari: Oribatida) některých vrchovišst' na Šumavě, jižní Čechy [Oribatid mites (Acari: Oribatida) of some Šumava peat bogs, south Czech]. Sbor. Jihočes. Muz. v Čes. Budějovicích Přír. Vědy 28: 99-107 (in Czech).

Toвolski T. 2000. Przewodnik do oznaczania torfów i osadów jeziornych [Guide for identification of peats and sediments]. PWN Warszawa, 1-508 (in Polish).

WaLgRam M. 1976. Über die Verbreitung der wasserbewohnenden Hornmilbengattung Hydrozetes Berlese 1902 (Acari, Oribatei) in Österreich [About the distribution of aquatic oribatid species Hydrozetes Berlese 1902 (Acari, Oribatei) in Austria]. Mitt. Naturwiss. Ver. Steiermark 106: 215-219 (in German).

Weigmann G. 2006. Hornmilben (Oribatida) [Oribatid mites (Oribatida)]. Die Tierwelt Deutschlands, vol. 76, Goecke and Evers, Keltern, 1-520 (in German).

Weigmann G., Deichsel R. 2006. 4. Acari: Limnic Oribatida. In: Süßwasserfauna von Mitteleuropa, 7/2-1 (Brauer A., Ed.), pp. 89-112, Elsevier, Spektrum Akademischer Verlag, München.

Willmann C. 1931. Moosmilben oder Oribatiden (Cryptostigmata) [Moss mites or Oribatids (Cryptostigmata)]. In: Die Tierwelt Deutschlands (DAHL F., Ed.), Bd. 22, vol. 5, pp. 79-200, Gustav Fischer, Jena (in German). 


\section{Biological Letters}

\section{INSTRUCTION TO AUTHORS}

\section{General information}

The semiannual journal Biological Letters is published in English and includes papers on all topics related to biology. It appears both in print and in open-access electronic format. We welcome submission of original articles, review articles, short communications, and proceedings of international conferences.

All papers must be in English. Authors whose native language is not English are encouraged to have their manuscripts read by a native English-speaking colleague before submission.

The manuscript should be double-spaced, with at least 3-cm left margin. It should not exceed 25 typed pages (including references, figures, and tables). The manuscript should be divided into the following sections:

1. Title page

1.1. Title

1.2. Complete name(s) of author(s)

1.3. Affiliation

1.4. Corresponding author

1.5. Received/Accepted dates

1.6. Running title

2. Abstract

3. Keywords

4. Introduction

5. Material and methods

6. Results

7. Conclusions

8. Acknowledgements

9. References

10. Figure captions

11. Figures

12. Tables

\section{Title page}

Title should be concise (see description of the article style)

Author(s) and affiliation. Give full forenames and surnames of author(s), affiliations and full postal address (without phone and fax numbers). Give the forename and surname of the corresponding author below affiliations. In the line below the corresponding author name and e-mail, add '(Received on ... )'.

Running title. Please provide a running title of no more than 60 characters (including spaces).

Abstract should be informative, i.e. should specify the objective, methods, and most important findings and conclusions of your paper. It should be limited to 250 words and should not contain literature citations or allusions to tables or figures.

Keywords. Avoid using words from the title as keywords. 


\section{Summary for manuscript details}

\begin{tabular}{|c|c|c|}
\hline General & \multicolumn{2}{|c|}{ Double-spaced, at least $3 \mathrm{~cm}$ left margin } \\
\hline Title & Bold, centred & Title \\
\hline Author(s) & $\begin{array}{l}\text { Name and surname in } \\
\text { capital letters, centred }\end{array}$ & $\begin{array}{c}\text { ZBIGNIEW ADAMSKI I,2, KATARZYNA FILA }{ }^{2}, \\
\text { JOLANTA MAĆKOWIAK }{ }^{3} \text { and KAZIMIERZ } \\
\text { ZIEMNICKI }^{2}\end{array}$ \\
\hline Affiliations & $\begin{array}{l}\text { Regular size font, } \\
\text { centred }\end{array}$ & $\begin{array}{c}\text { 1Electron and Confocal Microscope } \\
\text { Laboratory, Adam Mickiewicz University, } \\
\text { Umultowska 89, 61-614 Poznań, Poland } \\
\text { ²Department of Animal Physiology and } \\
\text { Developmental Biology, Adam Mickiewicz } \\
\text { University, 61-614 Poznań, } \\
\text { Poland }\end{array}$ \\
\hline Corresponding author & $\begin{array}{l}\text { Regular size font, } \\
\text { centred }\end{array}$ & $\begin{array}{l}\text { Corresponding author: Zbigniew Adamski, } \\
\text { ed@amu.edu.pl }\end{array}$ \\
\hline $\begin{array}{l}\text { Received/Accepted } \\
\text { dates }\end{array}$ & $\begin{array}{l}\text { Italic, centred, in } \\
\text { parenthesis }\end{array}$ & (Received ....; Accepted ...) \\
\hline Abstract & Bold, left & Abstract: \\
\hline Key words & Bold, left & Keywords: \\
\hline Textual headings & Capital letters, centred & $\begin{array}{c}\text { INTRODUCTION } \\
\text { MATERIAL AND METHODS } \\
\text { RESULTS } \\
\text { CONCLUSIONS } \\
\text { DISCUSSION } \\
\text { REFERENCES } \\
\text { TABLES } \\
\text { FIGURE SECTION }\end{array}$ \\
\hline Subsections & Italic, left & $\begin{array}{l}\text { Identification of specimens } \\
\text { Statistical analysis }\end{array}$ \\
\hline Acknowledgements & $\begin{array}{l}\text { Bold, regular size font, } \\
\text { left }\end{array}$ & Acknowledgements: \\
\hline Figures & & $\begin{array}{l}\text { In text: Fig. 1, Figs. 1-4 } \\
\text { Figure description: Fig. 1. Information }\end{array}$ \\
\hline Tables & & $\begin{array}{l}\text { In Text: Table 1, Table } 2 \\
\text { Table headline: Table 1. Information }\end{array}$ \\
\hline
\end{tabular}




\section{Species names}

International scientific names of all species used in the study (including authorship and year) must be supplied. Only the names of taxa lower than subfamily should be in italics.

Zoological nomenclature must be in agreement with the International Code of Zoological Nomenclature (4th edition 1999), which came into force on 1 January 2000. Author(s) of species names must be provided only at the first mention of each scientific name (the year of publication needs not be given as well as its full reference in the reference list). Authors of plant species names need not be given.

\section{Metric units}

Units must follow the SI system.

\section{References}

Author names should be written in SMALL CAPITAL letters. The references should be cited in the text as follows: (Sмith 1999) either (SMith \& Jones 1999) or (Brown et al. 1999). Consecutive references must be separated by a semicolon (;), and should be ordered chronologically. All papers cited in the text should be listed in the references section and all references should be cited in the text. The list of references should be ordered alphabetically by author's surname(s). Titles of papers published in languages other than English should be followed by their English translation in square brackets, with an explanatory note at the end, e.g. (in Russian).

When there is more than one reference of a given author in the same year, the references should be distinguished by the letter ' $a$ ' used for the first reference and ' $b$ ', 'c' for the following ones.

\section{Journal article}

Author(s). Year of publication. Title. Abbreviation of journal title. Volume: range of pages.

Example:

Hoekstra F. A., Golovina E. A., Buitink J. 2001. Mechanisms of plant desiccation tolerance. Trends Plant Sci. 6: 431-438.

\section{Journal article with DOI}

Author(s). Year of publication. Title. Abbreviation of journal title. DOI.

Example:

Matuszewski S., Bajerlein D., Konwerski S., Szpila K. 2009. Insect succession and carrion decomposition in selected forests of Central Europe. Part 2: Composition and residency patterns of carrion fauna. Forensic Sci. Int. doi:10.1016/j.forsciint.2009.11.007.

\section{Books}

Author(s). Year of publication. Title. Publisher, Publication place.

Example:

Efron B., Tibshirani R. J. 1993. An Introduction to the Bootstrap. Chapman \& Hall, London.

\section{Chapter in a book}

Author(s) of chapter. Year of publication. Chapter title. In: Book title (Editor(s) of the book, Ed(s)), Chapter range of pages, Publisher, Publication place.

Example:

Ling K. H., Paetkau V., Marcus S. F., Lardy H. A. 1966. Phosphofructokinase: skeletal muscle. In: Methods in Enzymology (Colwick S. P., Kaplan N. O., Eds), vol. 9, pp. 425-425, Academic Press, New York.

\section{Conference proceedings}

Author(s). Year of publication. Title. In: Conference name (Editor(s)), Date, Place of conference, Range of pages, Publisher, Publication place. 
Example:

Christian E. 2002. Copepoda from forest floor habitats in Vienna. In: Proceedings of the $6^{\text {th }}$ Central European Workshop on Soil Zoology (TajovskÝ K., Balík V., PižL V, Eds), April 23-25, 2001, České Budějovice, Czech Republic, pp. 19-24, Tisk Josef Posekaný, České Budějovice.

\section{Thesis or dissertation}

AutHor. Year of publication. Title. Information on thesis type, place of publication.

Example:

RosLin T. 1999. Spatial ecology of dung beetles. PhD thesis, University of Helisinki, Finland.

\section{Statistical conventions}

For significance tests, give the name of the test followed by a colon, the test statistic and its value, the degrees of freedom or sample size (whichever is the convention for the test), and the $P$ value. Degrees of freedom may be presented as a subscript to the test statistic, e.g. ANOVA: $F_{2,91}=3.24$, $P=0.002$, or $\left.r_{s}=-0.43, N=63, P<0.001\right) . P$ values should be expressed as an exact probability value. Departure from a significance threshold of 0.05 should be stated and justified in the Methods. Nonsignificant outcomes should be indicated as exact probability values or as 'ns'.

Figure caption

Captions to all figures should be grouped at the end of the text, on a separate page. They should be numbered consecutively: Fig. 1, Fig. 2, etc.

\section{Figures}

Figures should be inserted in Word as JPEG, GIF or TIF files, and grouped below Figure captions. The following resolutions are optimal: $600 \mathrm{dpi}$ for photographs, $300 \mathrm{dpi}$ for figures. They should be suitable for double reduction of size in reproduction (this is especially important when the size of symbols, inscriptions, descriptions of plots, line thickness, etc. are selected). References in the text to figures should be as follows: Fig. 1, Figs. 1-5.

\section{Tables}

Tables should be as simple as possible, and understandable without reference to the text. All tables with their captions should be grouped at the end of the text, below figures (each table on a separate page). Tables should not contain vertical rules, and the main body of the table should not contain horizontal rules. The supplementary descriptions should be added under the table. Give extra information as a footnote below the table. All tables should be referred as Table 1, etc., and numbered in the same order as they are mentioned in the main body of the article.

\section{Submission}

An electronic version of the manuscript (pdf), a cover letter, and a statement that the manuscript has not been published or submitted for publication elsewhere should be sent as attached files to the Managing Editor (Dr. Daria Bajerlein), e-mail: biollett@amu.edu.pl

\section{Editorial process}

Every manuscript is independently reviewed by at least two referees selected by editors before it is accepted for publication. Authors can provide names and addresses of at least three researchers of recognized competence who may be considered as reviewers. In e-submission, authors should be informed about manuscript acceptance or rejection within three months. In paper submission, the decision may take up to six months. The authors will receive galley proofs. They should be checked immediately and sent back to the editorial office within 48 hours. Corrections of the proofs must be restricted to printer's errors only. Otherwise, the authors would be charged for any other substantial changes in the proofs. The authors will receive 10 reprints and one copy of the volume free of charge. Further reprints may be ordered in the editorial office when the proofs are returned. 


\section{Page charges}

There are no page charges in our journal.

Standard submission to:

dr hab. Andrzej Lesicki

Department of Cell Biology

Institute of Experimental Biology

Adam Mickiewicz University

Umultowska 89

61-614 Poznań, Poland
Electronic submission to:

\section{dr Daria Bajerlein}

biollett@main.amu.edu.pl 